\title{
Comparison of SHF and SSF of wet exploded corn stover and loblolly pine using in-house enzymes produced from $T$. reesei RUT C30 and A. saccharolyticus
}

\author{
Vandana Rana, Anahita D Eckard and Birgitte K Ahring ${ }^{*}$
}

\begin{abstract}
The aim of the present study was to compare bioethanol production from wet exploded corn stover (WECS) and loblolly pine (WELP) hydrolyzed with in-house and commercial enzymes and fermented separately (SHF) and simultaneously (SSF). In-house enzymes produced from Trichoderma reesei, RUT-C30 and a novel fungal strain, Aspergillus saccharolyticus were loaded as 5 and $15 \mathrm{FPU} / \mathrm{g}$ glucan and supplemented with 10 and $30 \mathrm{CBU} / \mathrm{g}$ glucan, respectively. For hydrolysis and fermentation, slurries of WECS and WELP at 5 and 10\% (w/W) solids loading (SL) were utilized. Saccharomyces cerevisae was used for ethanol fermentation at $33^{\circ} \mathrm{C}$. Maximally, $15.6 \mathrm{~g} / \mathrm{L}$ and $13.4 \mathrm{~g} / \mathrm{L}$ (corresponding to theoretical ethanol yield of $76 \%$ and $67 \%$, respectively) were achieved in SSF process from WECS and WELP, respectively at 5\% SL and $15 \mathrm{FPU} / \mathrm{g}$ glucan loading of in-house enzymes. Ethanol concentrations in all cases were higher for SSF compared to SHF under same conditions. A cross comparison of SSF with commercial enzymes (Celluclast $1.5 \mathrm{~L}+$ Novozym 188) showed highest ethanol concentration of $17.3 \mathrm{~g} / \mathrm{L}$ and $15.4 \mathrm{~g} / \mathrm{L}$ (corresponding to theoretical ethanol yield of $84 \%$ and $77 \%$, respectively) from WECS and WELP, respectively at 5\% SL and $15 \mathrm{FPU} / \mathrm{g}$ glucan. These findings demonstrated that in-house enzymes were comparable to commercial enzymes as these fungi produced other lignocellulolytic enzymes beyond cellulase and hence enhanced the overall enzyme activity.
\end{abstract}

Keywords: Wet explosion; Wet exploded corn stover; Wet exploded loblolly pine; T. reesei Rut C30; A. saccharolyticus; Fermentation; SHF; SSF

\section{Introduction}

The cost and hydrolytic efficiency of lignocellulolytic enzymes are critical parameters in bioethanol production (Himmel et al. 1999; Lynd et al. 2005; Galbe and Zacchi 2002; Kovács et al. 2009). Thus, it is necessary to find microorganisms with better cellulolytic properties. The filamentous fungus Trichoderma reesei RUT-C30 has already been established as a producer of cellulases and hemicellulases which are extensively used in paper, pulp, food, feed and textile industries and recently, Trichoderma reesei RUT-C30 has been explored for its lignocellulolytic properties and hence is used in saccharification

\footnotetext{
* Correspondence: bka@tricity.wsu.edu

Bioproducts, Sciences and Engineering Laboratory (BSEL), Washington State University, 2710 Crimson Way, Richland, WA 99354-1671, USA
}

of lignocellulosic biomass to monomeric sugars for production biofuels (Bouws et al. 2008; Kumar et al. 2008).

Ethanol production from lignocellulosic biomass involves three core steps: i) Pretreatment ii) Enzymatic hydrolysis or saccharification iii) Fermentation. Hydrolysis of sugars followed by fermentation step is called separate hydrolysis and fermentation (SHF). As an alternative these hydrolysis and fermentation steps can be merged together in one process known as simultaneous saccharification and fermentation (SSF). There are pros and cons associated with both of these processes. An advantage of SHF is that enzymes and yeast can each operate at their optimal conditions, e.g. with respect to temperature, However, SHF has the disadvantage that inhibitory hydrolysis products accumulate, decreasing reaction rates (Stenberg et al. 2000; Xiao et al. 2004). In SSF, temperature 
is not optimal for cellulases and, therefore, the rate of hydrolysis is slow, but hydrolysis products can be consumed as they are formed due to fermentation, thus avoiding the inhibition seen with SHF (Ballesteros et al. 2004; Olsson et al. 2006). Furthermore, ethanol in the fermentation broth prevents significant microbial contamination. Another advantage of SSF is that the process integration of hydrolysis and fermentation in one reactor reduces the overall capital cost.

Although these processes to produce bioethanol are promising, the cost of added enzymes is substantial in many designs (Dutta et al. 2010; Kazi et al. 2010). One approach to reducing costs is use of at-site produced crude enzymes, which avoid costs for purification and transport (Schell et al. 1990; McMillan 1997). Another approach to achieving cost-savings is to eliminate filtration and washing after pretreatment, resulting in lower capital costs, less dilution, and higher product concentrations. However, pretreated slurry contains some sugar and lignin degradation products which are inhibitory to enzymes and yeast leading to decreased fermentation rates. Thus, it is important to employ a robust fermenting microorganism such as Saccharomyces cerevisiae, which shows high ethanol productivity and high tolerance to these inhibitory compounds (Olsson and HahnHägerdal 1993). In a previous study, it was found that some of these fermentation inhibitors can be completely metabolized by the yeast during SSF by metabolic redox reactions (Tomás-Pejó et al. 2008). In addition to the problems due to mass transfer in viscous pretreated material (Ingesson et al. 2001; Wen et al. 2004; Klinke et al. 2004), these inhibitory compounds restrict the maximum allowable water insoluble solid (WIS) in SSF and SHF processes (Linde et al. 2007).

In this study, SHF and SSF were performed on wet exploded corn stover and loblolly pine using in-house produced enzymes at two different concentrations of WIS and at two different enzyme loadings to determine which process is the most suited for the ethanol production. The influence of solid and enzyme loadings on ethanol yield were further evaluated using both in-house and commercial enzymes.

This research work confirms the novelty as no study has been reported up until now on the integration of process of in-house cellulase production by Trichoderma reesei Rut C30 \& Aspergillus saccharolyticus and ethanol production using those in-house produced cellulase cocktail from wet explosion pretreated corn stover and loblolly pine.

\section{Materials and methods Raw material}

Quarter inch corn stover and loblolly pine were kindly obtained from Iowa State University. Raw materials were milled to $2 \mathrm{~mm}$ size for compositional analysis and pretreatment. Composition of raw corn stover (\% dry matter basis) was as follows: glucan $38.7 \%$, xylan $25.2 \%$, galactan $1.83 \%$, arabinan $2.85 \%$, mannan $0.38 \%$, lignin $17.5 \%$, ash $2.6 \%$ and composition of raw loblolly was; glucan $35.9 \%$, xylan $8.5 \%$, galactan $2.5 \%$, arabinan $1.6 \%$, mannan $8.2 \%$, lignin $30.7 \%$, ash $0.8 \%$.

\section{Wet explosion pretreatment}

Wet explosion pretreatment was performed in a wet explosion pretreatment unit with a $10 \mathrm{~L}$ reactor described previously (Rana et al. 2012). In brief the corn stover was subject to pretreatment at $170^{\circ} \mathrm{C}$ for $20 \mathrm{~min}$ with 79.8 psi oxygen and loblolly pine was pretreated at $175^{\circ}$ $\mathrm{C}$ for $24 \mathrm{~min}$ at $79.8 \mathrm{psi}$ oxygen. These conditions were selected according to previous studies (data not shown) and based on optimal process conditions and sugar yields after enzymatic hydrolysis (Rana et al. 2013). Whole pretreated slurries were stored at $4^{\circ} \mathrm{C}$ for further studies.

A portion of pretreated slurry was divided into two fractions: (i) solid fraction or water insoluble solids (WIS) and (ii) liquid fraction or prehydrolyzate. To obtain the WIS, the solid fraction was washed with water multiple times and dried at $30^{\circ} \mathrm{C}$ for 4 days to obtain moisture content less than $10 \%$. Both fractions were analyzed for sugars, lignin and degradation products.

\section{Microorganisms}

Mutant fungi, Trichoderma reesei Rut-C30, and a novel fungi Aspergillus saccharolyticus (CBS 127449) were used for cellulase and $\beta$-glucosidase production, respectively as previously described (Rana et al. 2014).

\section{Preparation of biomass for enzyme production}

Corn stover was used as a substrate for cellulase production from $T$. reesei Rut-C30 and A. saccharolyticus. Quarter inch corn stover was milled to $1.5 \mathrm{~mm}$ and pretreated with wet explosion and subsequent subjected to alkali for T. reesei and just wet exploded for A. saccharolyticus. Pretreatment was conducted at the $100 \mathrm{~L}$ pilot plant facility of Washington State University using 25\% (D.M.) solid loading at $175^{\circ} \mathrm{C}$, for $25 \mathrm{~min}$ and an oxygen flow of $6.0 \%$. A portion of the wet exploded slurry was separated and liquor was used for A. saccharolyticus. The remaining portion of the pretreated biomass (wet exploded) was used for alkali pretreatment by subsequent supplementation with $1 \% \mathrm{w} / \mathrm{v} \mathrm{NaOH}$ at a solid loading of $10 \%(\mathrm{w} / \mathrm{v})$. Temperature was kept between $95-100^{\circ} \mathrm{C}$ for $5 \mathrm{~h}$ and $\mathrm{pH}$ of the resulting slurry was $\sim 11.0$. Combined wet explosion-alkali pretreated slurry was fractionated to give a liquor and pretreated biomass after centrifugation and subsequently dehydrated with a screw press before being used for enzyme production. Compositional analysis 
of pretreated biomass was conducted according to the NREL/TP-510-42618 procedure.

\section{Preparation of inoculum}

Inoculum cultures for fungal strain $T$. reesei RUT-C30 were prepared from $-80^{\circ} \mathrm{C}$ glycerol stocks on agar plates containing $39 \mathrm{~g} \mathrm{~L}^{-1}$ yeast extract potato dextrose (YPD) and incubated statically at $30^{\circ} \mathrm{C}$ for $120 \mathrm{~h}$. Colonies with surfaces were picked and went through consecutive transfers and streaking on the medium to obtain pure colonies. The composition of the medium was $30 \mathrm{~g} / \mathrm{l}$ wheat bran, $25 \mathrm{~g} / \mathrm{l}$ corn steep liquor (CSL), $5 \mathrm{~g} / \mathrm{l}$ Avicel, $50 \mathrm{~g} / \mathrm{l}$ glucose, $30 \mathrm{~g} / \mathrm{l}$ peptone and $5 \mathrm{~g} / \mathrm{l}$ yeast extract in a flask with a total volume of $150 \mathrm{ml} .50 \mathrm{ml}$ of autoclaved mineral solution was added to the media with the composition: $0.3 \mathrm{~g} / \mathrm{l}$ of $\mathrm{MgSO}_{4} .7 \mathrm{H}_{2} \mathrm{O}, 4 \mathrm{~g} / \mathrm{l}$ of $\mathrm{KH}_{2} \mathrm{PO}_{4}, 2 \mathrm{~g} / \mathrm{l}\left(\mathrm{NH}_{4}\right)_{2} \mathrm{SO}_{4}$ and $0.3 \mathrm{~g} / \mathrm{l}$ of $\mathrm{CaCl}_{2} \cdot 2 \mathrm{H}_{2} \mathrm{O}$. Media was inoculated with $3 \mathrm{ml}$ of spore's suspension, cooled, and the cultures were grown for $48 \mathrm{~h}$ at $30^{\circ} \mathrm{C}$ in a rotary shake at $140 \mathrm{RPM}$.

Inoculation media for A. saccharolyticus was prepared in $1000 \mathrm{ml}$ shake flasks with the active volume of $200 \mathrm{ml}$. The composition of inoculation media was $40 \mathrm{~g} / \mathrm{l}$ wheat bran, $40 \mathrm{~g} / \mathrm{l}$ corn steep liquor (CSL), $4 \mathrm{~g} / \mathrm{l}$ peptone, $2 \mathrm{~g} / \mathrm{l}$ yeast extract, $2 \mathrm{~g} / \mathrm{l}$ casamino acids, $12 \mathrm{~g} / \mathrm{l} \mathrm{NaNO}_{3}$,

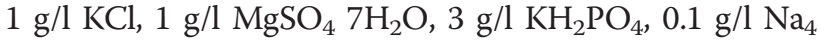
EDTA, $4.5 \mathrm{mg} / \mathrm{l} \mathrm{ZnSO}{ }_{4} 7 \mathrm{H}_{2} \mathrm{O}, 22 \mathrm{mg} / \mathrm{l} \mathrm{H}_{3} \mathrm{BO}_{3}, 10 \mathrm{mg} / \mathrm{l}$ $\mathrm{MnCl}_{2} 4 \mathrm{H}_{2} \mathrm{O}, 10 \mathrm{mg} / \mathrm{FeSO}_{4} 7 \mathrm{H}_{2} \mathrm{O}, 3.4 \mathrm{mg} \mathrm{CoCl} 26 \mathrm{H}_{2} \mathrm{O}$, $3.2 \mathrm{mg} / \mathrm{l} \mathrm{CuSO}_{4} 5 \mathrm{H}_{2} \mathrm{O}, 0.17 \mathrm{mg} / \mathrm{l} \mathrm{Na}_{2} \mathrm{MoO}_{4} 2 \mathrm{H}_{2} \mathrm{O}$. The media was sterilized by autoclave at $121^{\circ} \mathrm{C}$, for $15 \mathrm{~min}$. The inoculation media was left to equilibrate in a shake incubator set to operate at $28^{\circ} \mathrm{C}, 140 \mathrm{RPM}$. After equilibration the media was inoculated using $3 \mathrm{ml}$ spore suspension and the cultures were grown for $48 \mathrm{~h}$ at $30^{\circ} \mathrm{C}$ and $\mathrm{pH} 4.8$ in a rotary shaker.

\section{Enzyme production}

For enzyme production from $T$. reesei Rut-C30, $150 \mathrm{~mL}$ of the pre-culture was used to inoculate a $3 \mathrm{~L}$ stirred reactors. The airflow was kept at $1.2 \mathrm{~L} / \mathrm{min}$ and the stirrer speed at $800 \mathrm{rpm}$. The culture conditions were maintained at $28^{\circ} \mathrm{C}$ and at $\mathrm{pH} 3.75$ by automatic addition of 5 $\mathrm{NH}_{4} \mathrm{OH}$. The medium composition was as follows: $2.5 \%$ (DM) wet exploded-alkali pretreated corn stover, $2.5 \%$ corn steep liquor, $2.5 \%$ wheat bran, $0.05 \%$ yeast extract, $0.3 \%$ peptone, $5 \%$ corn mash (liquefied with $\alpha$-amylase to contain dextrin). The final volume was $1.8 \mathrm{~L}$ and the cells were cultured for $24 \mathrm{~h}$ after which the corn mash (with 33\% M.C.) was fed into the reactor in a fed-batch mode with an average initial dilution rate of $0.007 \mathrm{~h}^{-1}$. For saccharification of maltodextrin to D-glucose in corn mash, $300 \mu \mathrm{l}$ of gluco-amylase per liter of mash was mixed in the feed. To prevent bacterial growth during fermentation, $0.1 \% \mathrm{v} / \mathrm{v}$ of kanamycin was added to both the reactor and the feed bottle. $\beta$-glucosidase production from $A$. saccharolyticus was conducted in a stirred reactor $(5 \mathrm{~L})$ equipped with online control system for adjustment of $\mathrm{pH}$, temperature, antifoam, agitation and dissolved oxygen level (DO). The fermentation was performed in a feed batch setup. $800 \mathrm{ml}$ of inoculation media was used as a startup media, the media was added to the $5 \mathrm{~L}$ reactor for sterilization by autoclave at $121^{\circ} \mathrm{C}$ for $15 \mathrm{~min}$. After sterilization the reactor was stabilized for 4 hours at $28^{\circ} \mathrm{C}, \mathrm{pH} 4.8,800 \mathrm{RPM}$, aeration set-point was $0.7 \mathrm{~L}$ air $/ \mathrm{L} / \mathrm{m}$. The reactor was seeded using $200 \mathrm{ml}$ of inoculum as seed culture and, at 24 hours of operation the feed was started at $22 \mathrm{ml} / \mathrm{h}$, total fermentation time was 8 days. The enzyme containing liquid was filtered and consequently concentrated 10 times by rotary vacuum evaporation.

\section{Enzymes and activities}

Celluclast 1.5 L and Novozyme 188, were obtained from Sigma Aldrich. Filter-paper and Carboxymethyl cellulose activities were used as a measure of cellulase activity. FPA 4.49 FPU/mL and CMCase to $20.6 \mathrm{U} / \mathrm{mL}$ was measured after 7 days of fermentation. $\beta$-glucosidase activity on pNPG was measured as $4.77 \mathrm{U} / \mathrm{mL}$ and xylanase activity as $6.61 \mathrm{nkat} / \mathrm{mL}$. Commercial cellulase (celluclast $1.5 \mathrm{~L})$ showed $81.8 \mathrm{FPU} / \mathrm{mL}$ filter paper activity, $\beta$ glucosidase activity of $58.66 \mathrm{U} / \mathrm{mL}$ and xylanase activity $107.3 \mathrm{nkat} / \mathrm{mL}$. PNPG activities ( $\beta$-glucosidase) in $A$. saccharolyticus and in commercial enzyme Novozym 188 were $339.9 \mathrm{U} / \mathrm{mL}$ and $698.3 \mathrm{U} / \mathrm{mL}$, respectively.

\section{Yeast cultivation}

S. cerevisiae, a commercially available Baker's yeast was used for fermentation. Nutrient media contained glucose, $20 \mathrm{~g} / \mathrm{L}$; yeast extract, $10 \mathrm{~g} / \mathrm{L}$; proteose peptone, $20 \mathrm{~g} / \mathrm{L}$ and $\left(\mathrm{NH}_{4}\right)_{2} \mathrm{SO}_{4}, 3.42 \mathrm{~g} / \mathrm{L}$ were autoclaved at $121^{\circ} \mathrm{C}$ for $20 \mathrm{~min}$, cooled to room temperature and dry yeast cells were added to the nutrient medium. Four shake flasks with $100 \mathrm{~mL}$ working volume were incubated for $24 \mathrm{~h}$ at $33^{\circ} \mathrm{C}$ in a rotary shaker at $150 \mathrm{rpm}$.

\section{Separate hydrolysis and fermentation (SHF) with in-house enzymes}

Enzymatic saccharification was performed at 5 and $10 \%$ solids loading for 72 hours prior to the fermentation. Enzymes produced in-house from T. reesei and $A$. saccharolyticus mixture were added in two different loadings (i) $5 \mathrm{FPU} / g$ glucan $+10 \mathrm{CBU} / g$ glucan and (ii) $15 \mathrm{FPU} / \mathrm{g}$ glucan $+30 \mathrm{CBU} / \mathrm{g}$ glucan, respectively. Sterile salt solution $\left[\left(\mathrm{NH}_{4}\right)_{2} \mathrm{HPO}_{4}, 1.3 \mathrm{~g} / \mathrm{L} ; \mathrm{MgSO}_{4} .7 \mathrm{H}_{2} \mathrm{O}, 0.01 \mathrm{~g} / \mathrm{L}\right.$; $\mathrm{KH}_{2} \mathrm{PO}_{4}, 0.6 \mathrm{~g} / \mathrm{L}, 1 \%$ antibiotic kanamycin] needed for the fermentation were added during hydrolysis step to maintain the desired solid loading (5 and 10\%) throughout the process and also avoid further dilution during 
fermentation due to addition of salt solution. All hydrolysis runs were carried out in $250 \mathrm{~mL}$ shake flasks at $50^{\circ} \mathrm{C}, \mathrm{pH} 5$ and $150 \mathrm{rpm}$ for 72 hours.

The fermentation was started by addition of $1 \mathrm{~mL}$ of cell suspension of yeast yielding a cell concentration of $2 \mathrm{~g} \mathrm{~L}^{-1}$ dry weight (DW). The flasks were placed in a rotary shaker and operated at a shaker speed of $150 \mathrm{rpm}$ at a temperature of $33^{\circ} \mathrm{C}$ for $96 \mathrm{hrs} .1 .5 \mathrm{ml}$ samples were withdrawn periodically for analysis using a sterile syringe attached to a sampling tube.
Simultaneous saccharification and fermentation (SSF) with in-house enzymes

SSF experiments were conducted at similar experimental conditions as SHF. Pretreated slurry (5\% and 10\% WIS of WECS and WELP), sterile salt solution (5 mL $\left[\left(\mathrm{NH}_{4}\right)\right.$ ${ }_{2} \mathrm{HPO}_{4}, 1.3 \mathrm{~g} / \mathrm{L} ; \mathrm{MgSO}_{4} .7 \mathrm{H}_{2} \mathrm{O}, 0.01 \mathrm{~g} / \mathrm{L} ; \mathrm{KH}_{2} \mathrm{PO}_{4}, 0.6 \mathrm{~g} / \mathrm{L}$, $1 \%$ antibiotic kanamycin], enzymes (5 and $15 \mathrm{FPU} / \mathrm{g}$ glucan) and yeast cell suspension (cell concentration of $2 \mathrm{gL}^{-1}$ DW) were added in $250 \mathrm{~mL}$ shake flasks at a final working volume of $150 \mathrm{~mL}$ and kept at $33^{\circ} \mathrm{C}$ for $96 \mathrm{~h}$.

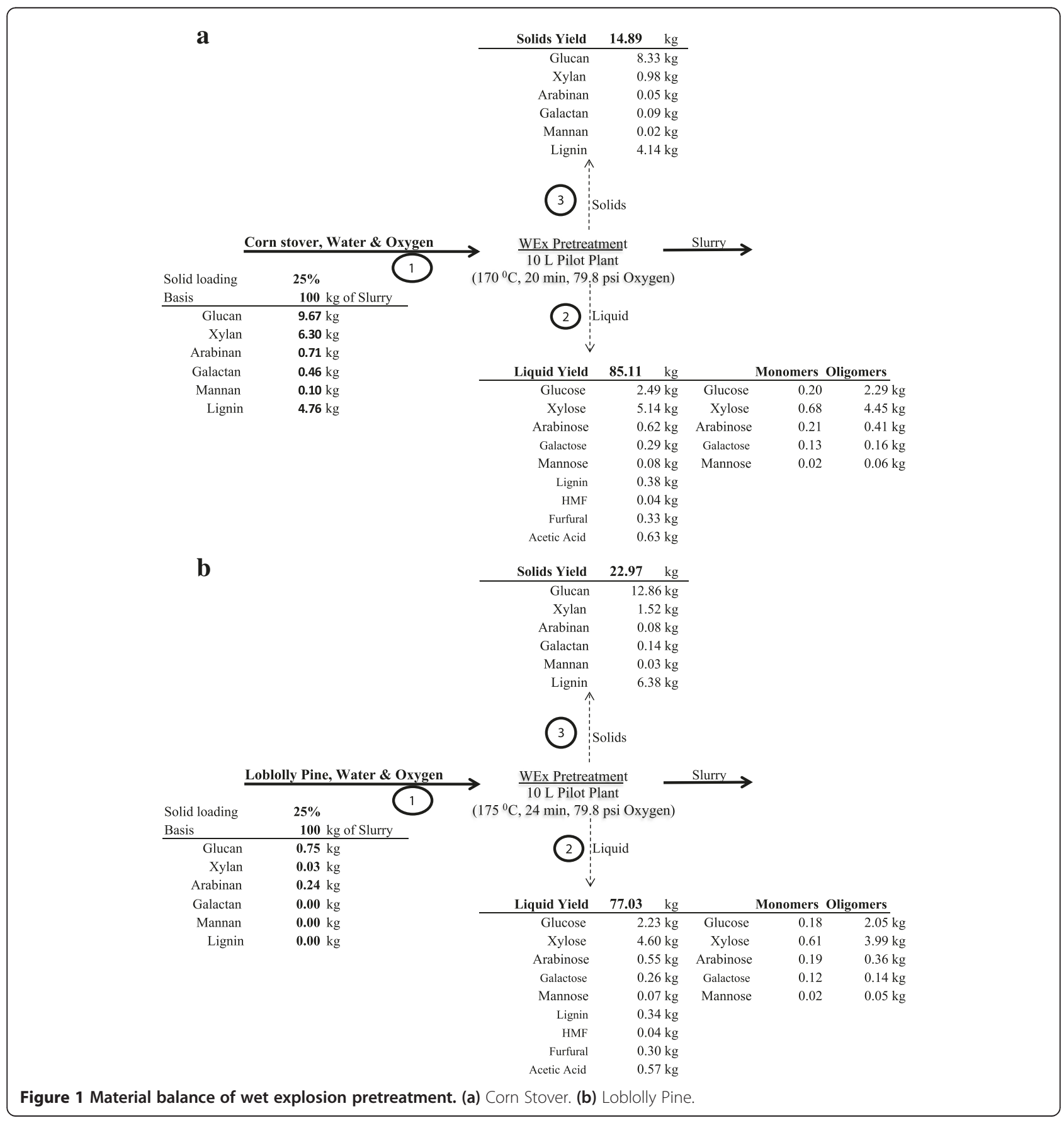


Periodically, $1.5 \mathrm{ml}$ samples were taken and centrifuged and clear samples were analyzed for ethanol, residual sugars and glycerol using HPLC. Dry mass of the yeast inoculum was determined according to NREL/TP510-42630 protocol. The volumetric ethanol productivity was calculated based on ethanol concentration after 96 hours divided by total hours. Theoretical ethanol yield was calculated based on Eq. (1)

$$
\% \text { Theoretical ethanol yield }=\frac{[\text { EtOH }]_{\text {final }}-[\text { EtOH }]_{0}}{0.51 \times[\text { Glucan } \times 1.11]} \times 100
$$

\section{Analytical methods}

The pretreated materials were analyzed using NREL's laboratory analytical procedure for determination of structural carbohydrates and lignin in biomass (NREL/TP-51042618). Dry matter content of the slurry was determined by drying the material overnight at $105^{\circ} \mathrm{C}$. Sugars, sugars degradation products (furfural, 5-hydroxymethylfurfural (HMF) and acetic acid) and ethanol were measured using high performance liquid chromatography, HPLC (Agilent Technologies, Santa Clara, CA) using an Aminex ion exclusion HPX-87H cation-exchange column (Bio-Rad, Hercules, CA) at $60^{\circ} \mathrm{C}$ with a flow rate of $0.6 \mathrm{ml} / \mathrm{min}$ with $5 \mathrm{mM}$ sulfuric acid as the mobile phase. Peaks were identified using refractive index (RI) detector at $60^{\circ} \mathrm{C}$.

Dry cell mass of the yeast inoculum was measured according to NREL/TP-510-42630 by centrifuging $8 \mathrm{ml}$ of inoculum at $4000 \mathrm{rpm}$ for $5 \mathrm{~min}$. Supernatant was discarded and pellets were washed twice with $5 \mathrm{ml}$ deionized water and centrifuged. After washing the pellets were dried in a convection oven at $105^{\circ} \mathrm{C}$ until constant weight was obtained.

\section{Results}

The pretreated corn stover and loblolly pine were saccharified using in-house produced cellulases and commercial cellulases and were used for fermentation by Saccharomyces cerevisae. Fermentation yields using inhouse and commercial enzymes were compared.

\section{Fermentation substrate-wet exploded corn stover \& loblolly pine}

Wet explosion is a combination of wet oxidation and steam explosion in which wet oxidized biomass is suddenly depressurized/exploded (Rana et al. 2012). Slurries with total solids contents of $23 \%$ and $25 \%$ (w/w) were obtained after wet explosion pretreatment of corn stover and loblolly pine, respectively. The mass balance of the pretreated materials is given in Figure 1a \& b. $2.49 \mathrm{~kg}$ of glucose corresponding to $23 \%$ overall conversion was obtained from wet exploded corn stover and, $2.23 \mathrm{~kg}$ of glucose corresponding to $21 \%$ conversion from wet exploded loblolly pine. Resulting sugars as well as sugar degradation products are also shown in Figure 1. It can be concluded that most of hemicellulosic sugars were solubilized and are present mainly in oligomeric form. Very little lignin was solubilized (1\% solubilized) during the wet explosion pretreatment. Furfural $3.99 \mathrm{~g} / \mathrm{L}$ and

Table 1 Fermentation using in-house enzymes produced from $T$. reesei and $A$. saccharolyticus

\begin{tabular}{|c|c|c|c|c|c|c|}
\hline & $\begin{array}{l}\text { Enzyme loading } \\
\text { (FPU/g glucan) }\end{array}$ & Solid loading (g/L) & Ethanol conc. (g/L) & Glycerol conc. (g/l) & $Y_{\text {EtOH/Glu }}(\%)$ & Qp EtOH/Gluc (g/l.h) \\
\hline \multirow[t]{4}{*}{ Corn stover - (SHF) } & 5 & 50 & $12.86 \pm 0.02$ & $0.30 \pm 0.03$ & 62.61 & 0.13 \\
\hline & 15 & 50 & $14.41 \pm 0.08$ & $0.69 \pm 0.05$ & 70.19 & 0.15 \\
\hline & 5 & 100 & $23.23 \pm 1.10$ & $1.28 \pm 0.25$ & 56.56 & 0.24 \\
\hline & 15 & 100 & $26.83 \pm 0.00$ & $1.40 \pm 0.00$ & 65.33 & 0.28 \\
\hline \multirow[t]{4}{*}{ Corn stover - (SSF) } & 5 & 50 & $13.59 \pm 0.08$ & $0.35 \pm 0.01$ & 66.19 & 0.14 \\
\hline & 15 & 50 & $15.60 \pm 0.12$ & $0.56 \pm 0.01$ & 75.98 & 0.16 \\
\hline & 5 & 100 & $25.68 \pm 0.19$ & $1.02 \pm 0.01$ & 62.53 & 0.27 \\
\hline & 15 & 100 & $28.42 \pm 1.09$ & $1.35 \pm 0.06$ & 69.21 & 0.30 \\
\hline \multirow[t]{4}{*}{ Loblolly pine - (SHF) } & 5 & 50 & $9.29 \pm 0.74$ & $0.27 \pm 0.05$ & 46.51 & 0.10 \\
\hline & 15 & 50 & $12.50 \pm 0.13$ & $0.27 \pm 0.00$ & 62.54 & 0.13 \\
\hline & 5 & 100 & $16.29 \pm 0.51$ & $0.53 \pm 0.00$ & 40.77 & 0.17 \\
\hline & 15 & 100 & $23.33 \pm 0.01$ & $0.56 \pm 0.03$ & 58.37 & 0.24 \\
\hline \multirow[t]{4}{*}{ Lobllolly pine - (SSF) } & 5 & 50 & $11.93 \pm 0.01$ & $0.33 \pm 0.00$ & 59.70 & 0.12 \\
\hline & 15 & 50 & $13.40 \pm 0.12$ & $0.40 \pm 0.01$ & 67.07 & 0.14 \\
\hline & 5 & 100 & $19.96 \pm 0.34$ & $0.48 \pm 0.01$ & 49.96 & 0.21 \\
\hline & 15 & 100 & $24.98 \pm 0.32$ & $0.56 \pm 0.03$ & 62.51 & 0.26 \\
\hline
\end{tabular}


Table 2 Fermentation using commercial enzymes (Celluclast $1.5 \mathrm{~L}$ and Novozym 188)

\begin{tabular}{|c|c|c|c|c|c|c|}
\hline & $\begin{array}{l}\text { Enzyme loading } \\
\text { (FPU/g glucan) }\end{array}$ & Solid loading (\%) & Ethanol concentration $(\mathrm{g} / \mathrm{L})$ & Glycerol (g/l) & $Y_{\text {EtOH/Glu }}(\%)$ & $Q p_{\text {EtOH/Gluc }}(g / l . h)$ \\
\hline \multirow[t]{4}{*}{ Corn stover - (SSF) } & 5 & 5 & $13.83 \pm 0.49$ & $0.99 \pm 0.34$ & 67.37 & 0.14 \\
\hline & 15 & 5 & $17.28 \pm 1.31$ & $0.77 \pm 0.00$ & 84.14 & 0.18 \\
\hline & 5 & 10 & $27.51 \pm 1.49$ & $1.33 \pm 0.01$ & 66.98 & 0.29 \\
\hline & 15 & 10 & $32.53 \pm 0.15$ & $0.36 \pm 0.01$ & 79.21 & 0.34 \\
\hline \multirow[t]{4}{*}{ Loblolly pine - (SSF) } & 5 & 5 & $12.40 \pm 0.04$ & $0.04 \pm 0.00$ & 62.04 & 0.13 \\
\hline & 15 & 5 & $15.42 \pm 0.01$ & $0.04 \pm 0.00$ & 77.19 & 0.16 \\
\hline & 5 & 10 & $20.98 \pm 0.21$ & $0.15 \pm 0.06$ & 52.50 & 0.22 \\
\hline & 15 & 10 & $27.08 \pm 0.08$ & $0.12 \pm 0.01$ & 67.77 & 0.28 \\
\hline
\end{tabular}

$1.29 \mathrm{~g} / \mathrm{L}$ from CS and LP respectively was formed due to pentose degradation and HMF $0.5 \mathrm{~g} / \mathrm{L}$ and $0.71 \mathrm{~g} / \mathrm{L}$ from hexose degradation in pretreated liquor of corn stover and loblolly pine, respectively. Acetic acid $7.57 \mathrm{~g} / \mathrm{L}$ and $3.58 \mathrm{~g} / \mathrm{L}$ were released from corn stover and loblolly pine, respectively due to solubilization of acetyl groups present in the hemicellulose. These degradation compounds are considered inhibitory for the fermentation.
These inhibitors have been previously been identified in corn stover, wheat straw, barley straw (García-Aparicio et al. 2006; Öhgren et al. 2005; Oliva et al. 2003).

\section{SHF of WECS and WELP with enzyme mixtures produced} in-house

SHF with two different solids loadings (5\% and 10\%) at two enzymes loadings (5 and $15 \mathrm{FPU} / \mathrm{g}$ glucan), was

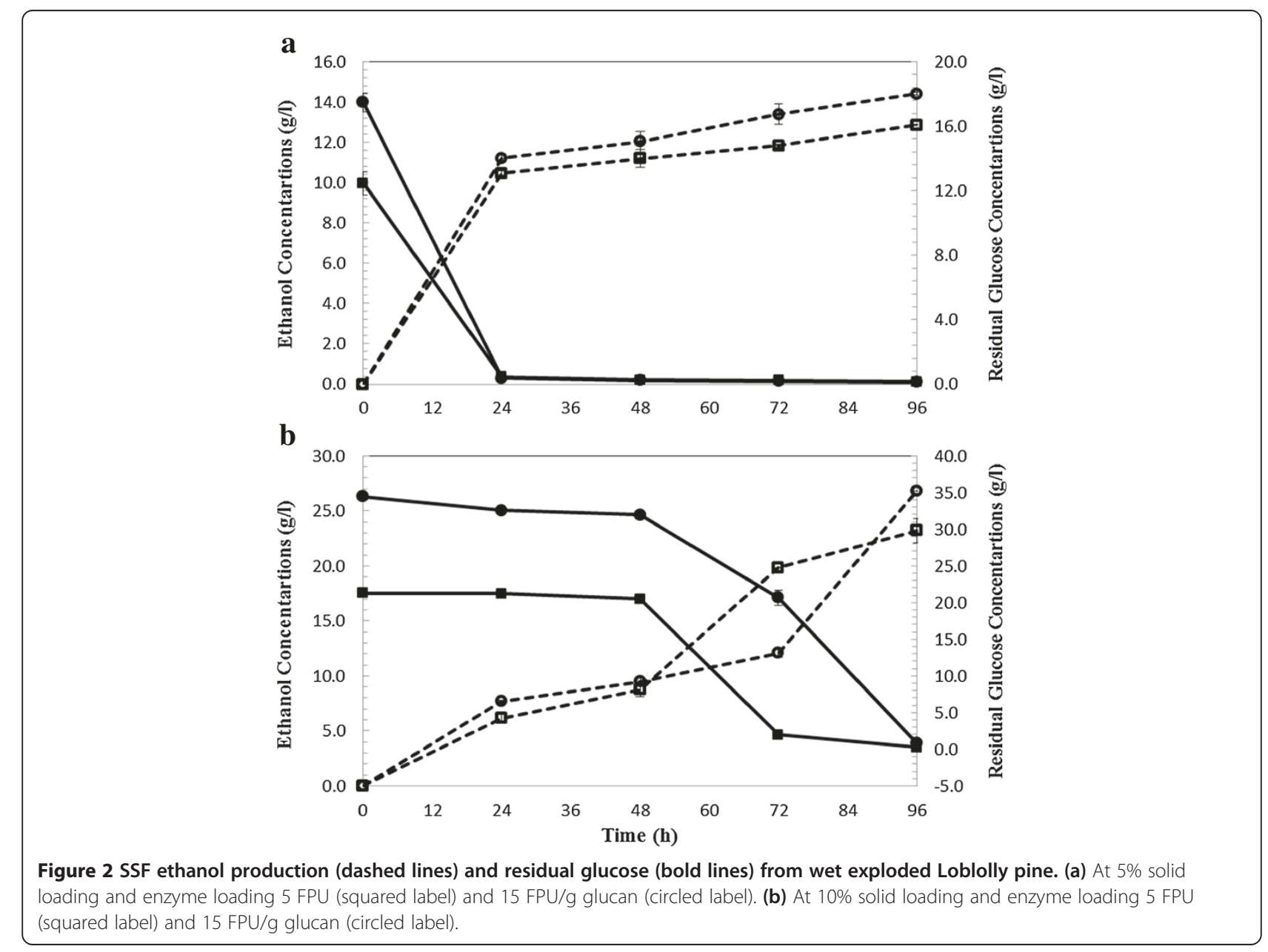


evaluated with regard to ethanol yield for WECS and WELP using in-house enzymes produced and commercial enzymes as shown in Tables 1 and 2 respectively. Figures 2 and 3 show the final glucose and ethanol concentrations and glucose consumption rate over the period of 96 hours of fermentation of wet exploded corn stover.

For SHF of WECS, at 5\% solid loading (Figure 2a), the maximum ethanol concentration was 12.86 and $14.41 \mathrm{~g} / \mathrm{L}$ in CS-1 and CS-2, respectively. All the glucose was exhausted during the first 24 hours and was consumed at a linear rate, slightly decreasing with time. After $96 \mathrm{~h}$ a residual glucose concentration of $1 \mathrm{~g} / \mathrm{L}$ was found in CS-1 and CS-2 hydrolyzates. Glycerol is one of the major byproducts during biomass (glucose) conversion to ethanol (Zaldivar et al. 2005) and at the stationary phase (no cell growth) glycerol production ceases. $0.3 \mathrm{~g} / \mathrm{L}$ and $0.7 \mathrm{~g} / \mathrm{L}$ of glycerol were formed respectively in CS-1 and CS-2 demonstrating that glucose was mainly consumed for the ethanol production.

Increased solids loading and decreased enzyme loading (10\%, $5 \mathrm{FPU} / \mathrm{g}$ glucan) lowered the ethanol yield in SHF of WECS. At $10 \%$ solids loading and cellulase loading of $5 \mathrm{FPU} / \mathrm{g}$ glucan (CS-3) (Figure 2b), an ethanol concentration of $23.23 \mathrm{~g} / \mathrm{L}$ corresponding to the ethanol yield of $56.6 \%$ was achieved. With increasing enzyme loading to $15 \mathrm{FPU} / \mathrm{g}$ glucan (CS-4), resulted in an ethanol concentration of $26.83 \mathrm{~g} / \mathrm{L}$ corresponding to a yield of $65.3 \%$. Glucose was exhausted gradually; only 0.24 and $0.82 \mathrm{~g} / \mathrm{L}$ of glucose remained in CS-3 and CS-4 after 96 hours of fermentation. Glycerol concentrations of $1.3 \mathrm{~g} / \mathrm{L}$ and $1.4 \mathrm{~g} / \mathrm{L}$ resulted, respectively, in CS-3 and CS-4.

Figure 3 shows the ethanol production and glucose consumption during 96 hours of SHF of loblolly pine at 5\% SL (Figure 3a) and 10\% SL (Figure 3b). At 5\% solid loading (Figure 3a), the maximum ethanol concentrations were 9.29 and $11.03 \mathrm{~g} / \mathrm{L}$ in LP-1 (5 FPU/g glucan) and LP-2 (15 FPU/g glucan), respectively after 96 hours. All the glucose was exhausted during the first 24 hours and was consumed at a linear rate. Less than $0.5 \mathrm{~g} / \mathrm{L}$ of glucose remained in LP-1 and LP-2 hydrolyzate at the completion of the fermentation. $0.26 \mathrm{~g} / \mathrm{L}$ and $0.27 \mathrm{~g} / \mathrm{L}$ of glycerol were formed, respectively, in LP-1 and LP-2 demonstrating that glucose was mainly consumed for

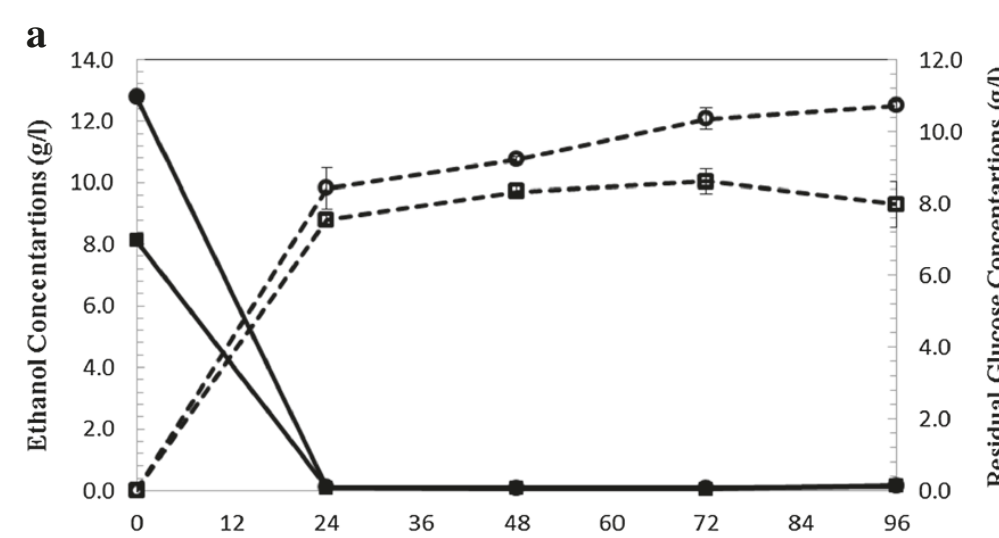

b

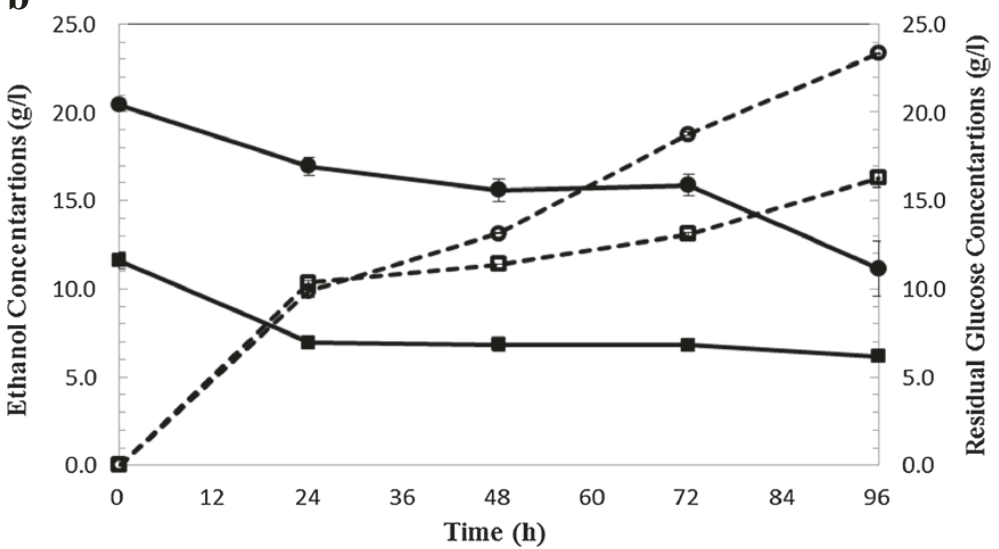

Figure 3 SHF ethanol production (dashed lines) and residual glucose (bold lines) from wet exploded Loblolly pine. (a) At $5 \%$ solid loading and enzyme loading 5 FPU (squared label) and 15 FPU/g glucan (circled label). (b) At 10\% solid loading and enzyme loading 5 FPU (squared label) and $15 \mathrm{FPU} / \mathrm{g}$ glucan (circled label). 
ethanol production. At 10\% solids loading (Figure 3b), the maximum ethanol concentrations were 16.29 and $23.33 \mathrm{~g} / \mathrm{L}$ in LP-3 (5FPU/g glucan) and LP-4 (15 FPU/g glucan), respectively. Glucose consumption was slower compared to LP-1 and LP-2 and 6.19 and $11.15 \mathrm{~g} / \mathrm{L}$ of glucose remained in LP-3 and LP-4 after 96 hours of fermentation. $0.53 \mathrm{~g} / \mathrm{L}$ and $0.56 \mathrm{~g} / \mathrm{L}$ of glycerol were formed respectively in LP-3 and LP-4.

\section{SSF of WECS and WELP with enzyme mixtures produced on-site}

SSF experiments were conducted with similar process condition, $5 \%$ and $10 \%$ solid loadings and 5 and 15 FPU/ g glucan enzyme loadings of on-site produced enzymes for fermentation of WECS and WELP. Figure 4 shows ethanol production and glucose consumption over the period of 96 hours of fermentation of WECS. At 5\% solids loading (Figure 4a), the maximum ethanol concentration was 13.59 and $15.60 \mathrm{~g} / \mathrm{L}$ in CS-1 and CS-2, respectively. Less than $1 \mathrm{~g} / \mathrm{L}$ of glucose remained in CS1 and CS- 2 after fermentation. $0.35 \mathrm{~g} / \mathrm{L}$ and $0.56 \mathrm{~g} / \mathrm{L}$ of glycerol were formed in CS-1 and CS-2, respectively at the end of the fermentation. The maximum ethanol concentration was 25.68 and $28.42 \mathrm{~g} / \mathrm{L}$ in CS-3 and CS-4, respectively. Glucose was exhausted gradually; only 0.50 and $1.67 \mathrm{~g} / \mathrm{L}$ of glucose remained in CS-3 and CS-4 after 96 hours of fermentation. $1.01 \mathrm{~g} / \mathrm{L}$ and $1.35 \mathrm{~g} / \mathrm{L}$ of glycerol were formed respectively in CS-3 and CS-4.

Figure 5 shows ethanol production and glucose consumption over the period of 96 hours of fermentation of loblolly pine. At $5 \%$ solids loading (Figure $5 \mathrm{a}$ ), the maximum ethanol concentration was 11.93 and $13.40 \mathrm{~g} / \mathrm{L}$ in LP-1 and LP-2, respectively. Less than $0.5 \mathrm{~g} / \mathrm{L}$ of glucose remained in LP-1 and LP-2 after fermentation. $0.33 \mathrm{~g} / \mathrm{L}$ and $0.40 \mathrm{~g} / \mathrm{L}$ of glycerol were formed respectively in LP1 and LP-2 demonstrating that glucose was mainly consumed for ethanol production. At 10\% solids loading (Figure $5 \mathrm{~b}$ ), the maximum ethanol concentration was 19.96 and $24.98 \mathrm{~g} / \mathrm{L}$ corresponding to $50 \%$ and $62.5 \%$ yield in LP-3 and LP-4, respectively. Glucose increased rapidly during the first 24 hours and remained at a stable level for 24 hours after which it decreased. 8.32

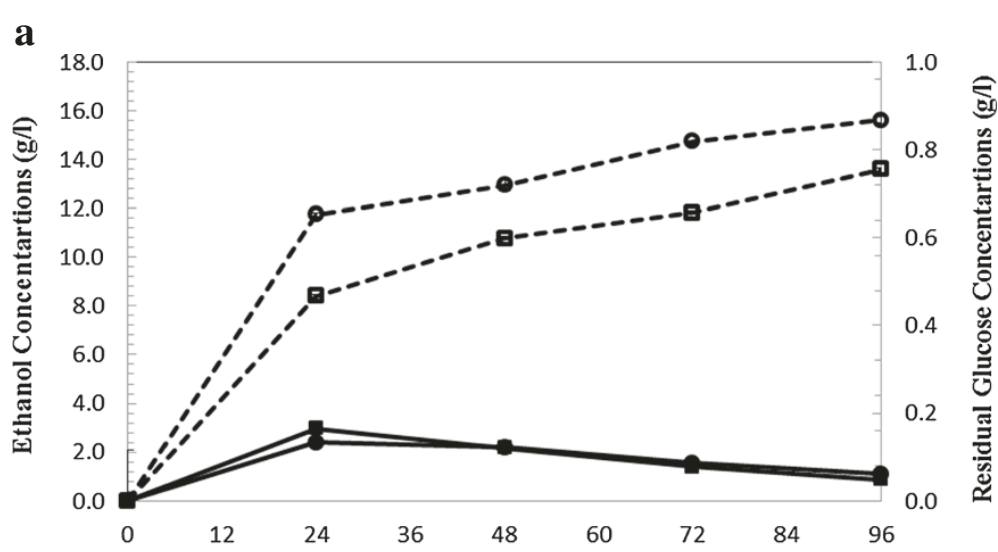

b

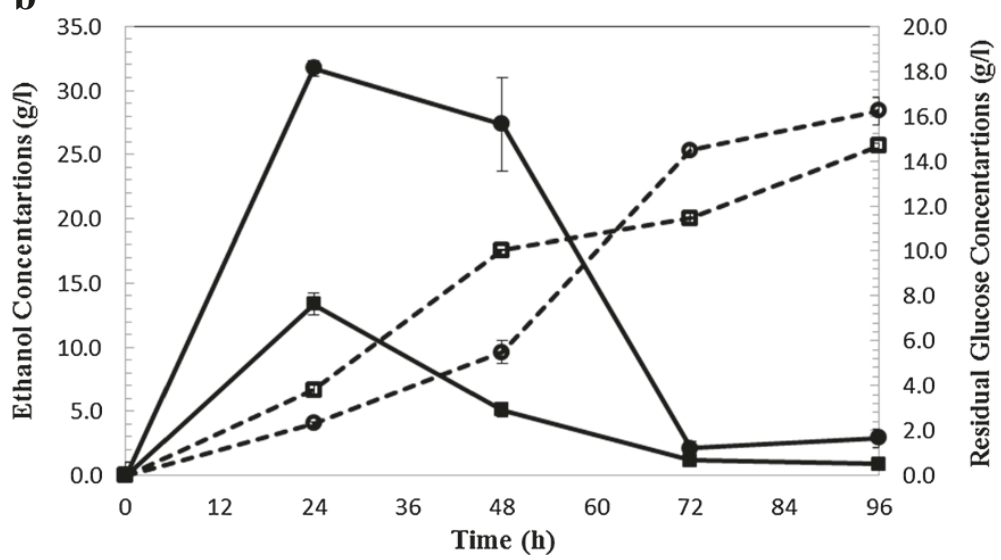

Figure 4 SSF ethanol production (dashed lines) and residual glucose (bold lines) from wet exploded corn stover. (a) At $5 \%$ solid loading and enzyme loading 5 FPU (squared label) and 15 FPU/g glucan (circled label). (b) At 10\% solid loading and enzyme loading 5 FPU (squared label) and $15 \mathrm{FPU} / \mathrm{g}$ glucan (circled label). 


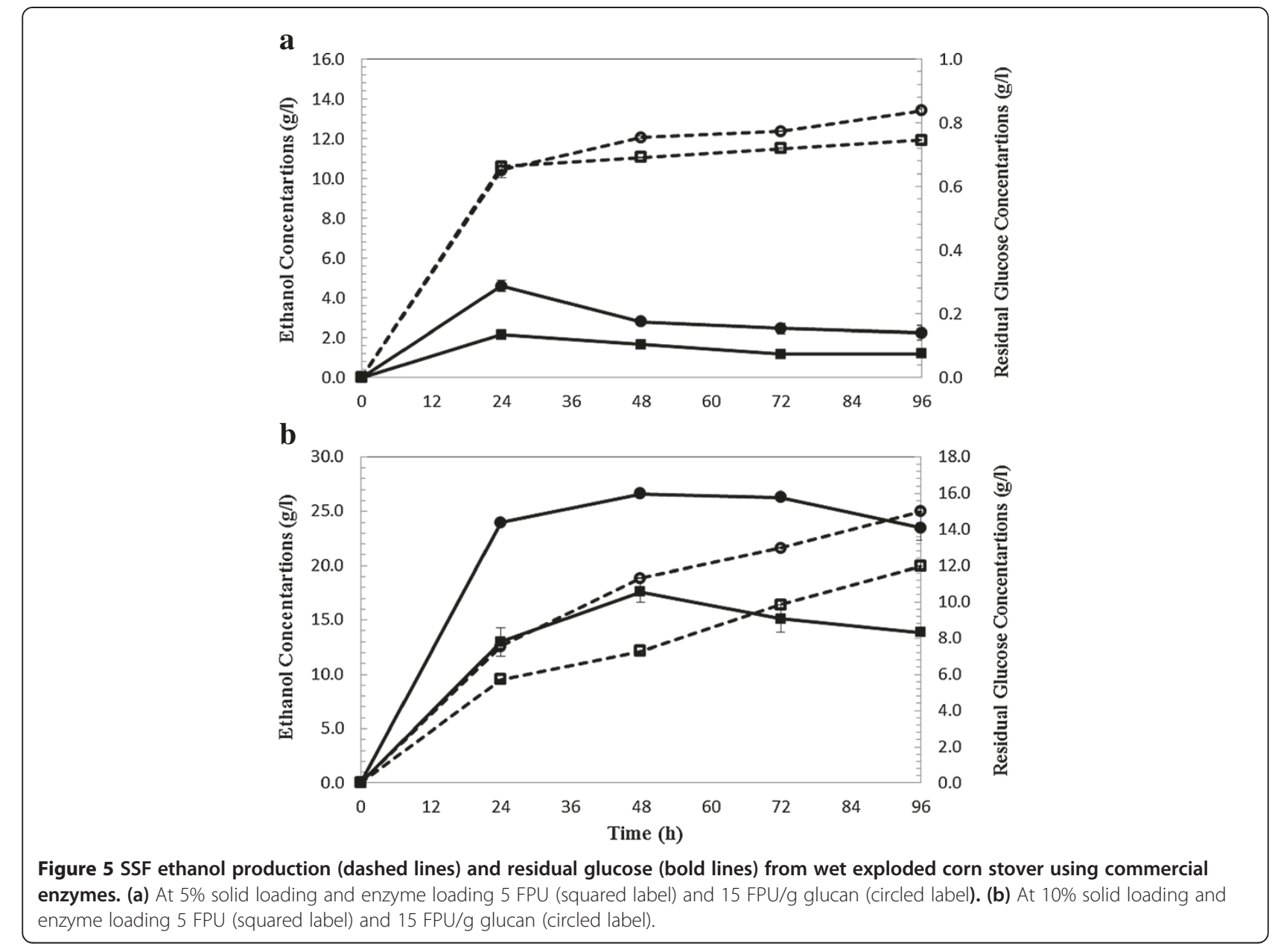

and $14.09 \mathrm{~g} / \mathrm{L}$ of glucose remained in LP-3 and LP-4 after 96 hours of fermentation. $0.48 \mathrm{~g} / \mathrm{L}$ and $0.56 \mathrm{~g} / \mathrm{L}$ of glycerol were formed respectively in LP-3 and LP-4.

\section{Comparative analysis of SSF with commercial enzymes} In order to compare ethanol production in the SSF process with commercial enzymes (celluclast $1.5 \mathrm{~L}$ and Novozym 188 ) and in-house produced enzymes (T. reesei and $A$. saccharolyticus), SSF runs were conducted on WECS and WELP (Figures 6 and 7) at 5 and 10\% solids loadings. Several authors have agreed on the feasibility of SSF process at high solid loading (10\% w/w) (Ballesteros et al. 2004; Linde et al. 2006; Öhgren et al. 2006). Fermentations of WECS and WELP hydrolyzed with commercial and on-site produced enzymes were compared under identical conditions.

The highest ethanol from wet exploded corn stover was achieved at $15 \mathrm{FPU} / \mathrm{g}$ glucan and 5\% solids loadings (75\% and $84 \%$ of theoretical yield for in-house and commercial enzymes, respectively). The highest ethanol from wet exploded loblolly pine was achieved at $15 \mathrm{FPU} / \mathrm{g}$ glucan and 5\% solids loadings $(67 \%$ and $77 \%$ for inhouse and commercial enzymes, respectively).

\section{Discussion}

In this study, cellulolytic enzymes were produced inhouse using $T$. reesei Rut C30 and A. saccharolyticus to reduce the cost of enzymatic hydrolysis and still keep high hydrolysis efficiency. Our results showed that we had all the necessary cellulolytic activities by combining the two selected fungal species. In-house produced enzymes showed higher filter paper activity (FPA), 4.8FPU/mL from T. reesei Rut C30 compared to other authors (Juhász et al. 2005; Kovács et al. 2009). In contrast to the huge difference in FPAs for T. reesei Rut C30 and commercial Celluclast $1.5 \mathrm{~L}$ (4.5 and $80 \mathrm{FPU} / \mathrm{mL}$, respectively), the measured $\beta$-glucosidase activity of the $A$. saccharolyticus was about half of Novozym 188. This is possibly due to the fact that $\beta$-glucosidase activity is measured on a simple substrate and not influenced by other enzyme activities, whereas FPA is determined on a complex substrate where several different bonds needs to be cleaved by different enzymes (Kovács et al. 2009).

In this study, in-house cellulase performance was compared with the traditional cellulase mixture, Celluclast $1.5 \mathrm{~L}$ and Novozym 188 instead of newer commercial 

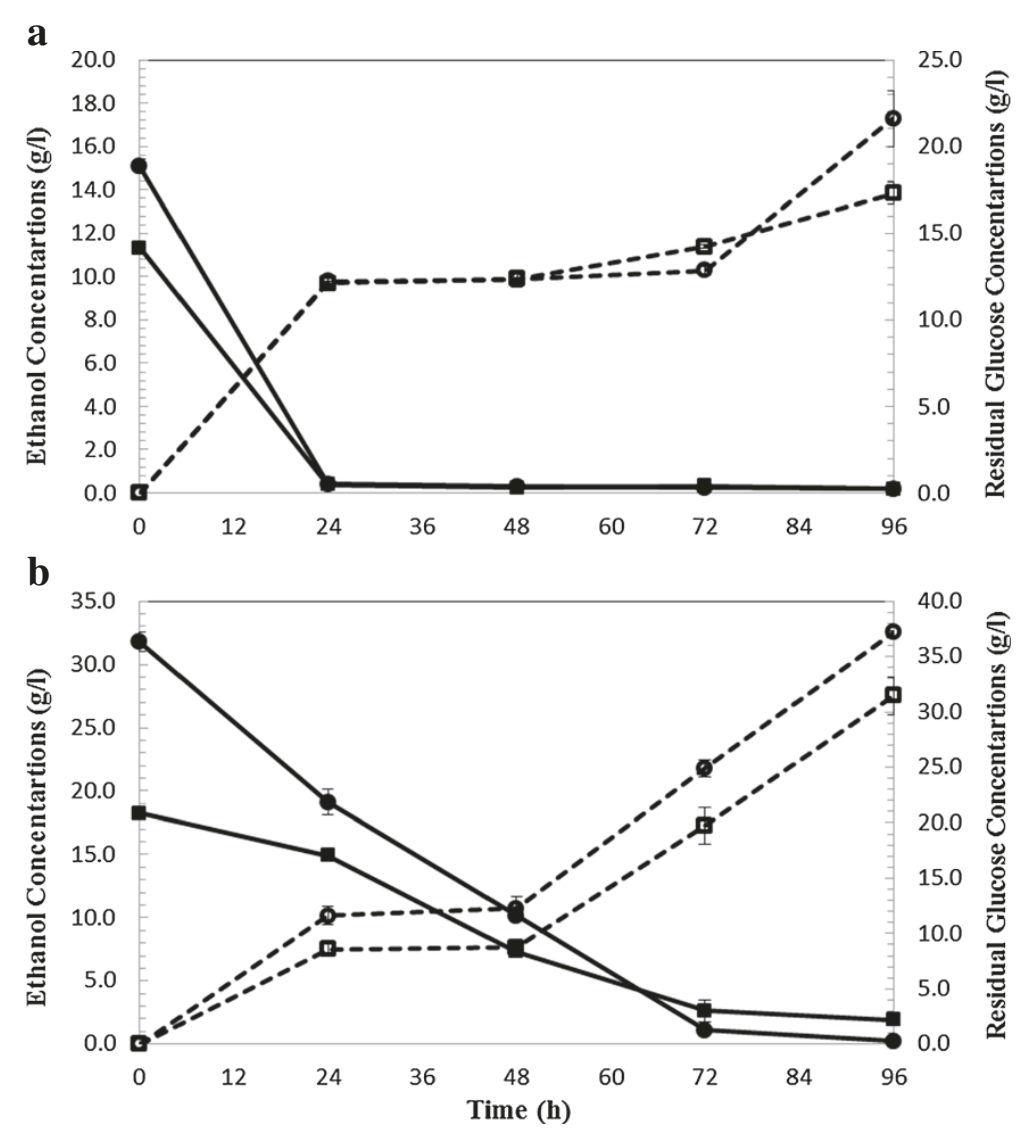

Figure 6 SSF ethanol production (dashed lines) and residual glucose (bold lines) from wet exploded corn stover using commercial enzymes (a) at $5 \%$ solid loading and enzyme loading $5 \mathrm{FPU}$ (squared label) and $15 \mathrm{FPU} / \mathrm{g}$ glucan (circled label) (b) at $10 \%$ solid loading and enzyme loading 5 FPU (squared label) and $15 \mathrm{FPU} / \mathrm{g}$ glucan (circled label).

cellulase preparations because recipe of new enzymes formulation is not known and also these enzymes' performance is a result of multiple accessory enzymes present in the formulation (Rana et al. 2014). Therefore for the purpose of the study, comparison was made with known cellulase mixture, Celluclast and Novozym. The selection of a maximum of $10 \%$ solids loading was supported by previous findings that the better fermentation results are obtained when the solids loading is limited to $10 \%$ (Varga et al. 2004). In our preliminary studies with higher solids loading (20\%) similar results were found and due to mixing problems and mass transfer issues only low levels of fermentation products were obtained (data not shown). Stenberg et al. (Stenberg et al. 2000) found similar limitations with steam-pretreated softwood. Other authors who were able to successfully apply a higher solids loading (>10\%) used commercial enzymes with higher loadings (20-45 FPU/g glucan) (Linde et al. 2007; Stenberg et al. 2000; Varga et al. 2004).

In SHF, the maximally achieved theoretical ethanol yield were $70.2 \%$ and $62.5 \%$ from WECS and WELP, respectively, using $5 \%$ solids loading and $15 \mathrm{FPU} / \mathrm{g}$ glucan after 96 hours of fermentation. At the higher solids loading (10\%) of WECS and WELP, sugar consumption was slow and delayed probably because of the presence of higher amounts of inhibitors in the hydrolyzate. Yeasts are not capable of metabolizing acids such as acetic acid under anaerobic conditions, but they are able to reduce the pentose and hexose driven aldehydic inhibitors (furfural and HMF) to their corresponding alcohols and this leads to reduced ethanol productivity until all the furfural/HMF has been consumed (Taherzadeh et al. 1999). Complete assimilation of these aldehydes takes time and results in a long lag phase before ethanol production (Liu et al. 2004; Taherzadeh et al. 2000).

In SSF, the highest achieved theoretical ethanol yields were $75.9 \%$ and $67.1 \%$ from WECS and WELP, respectively, using 5\% solids loading and 15 FPU/g glucan after 96 hours of fermentation. Similar to SHF, at high solids loading, 10\% (Figure 4b), the higher amounts of inhibitors were present in the medium which might have influenced the cells growth significantly as demonstrated by an increased lag phase (Taherzadeh et al. 2000). As can be seen in Figure 4b and 5b with solids loading 10\%, 

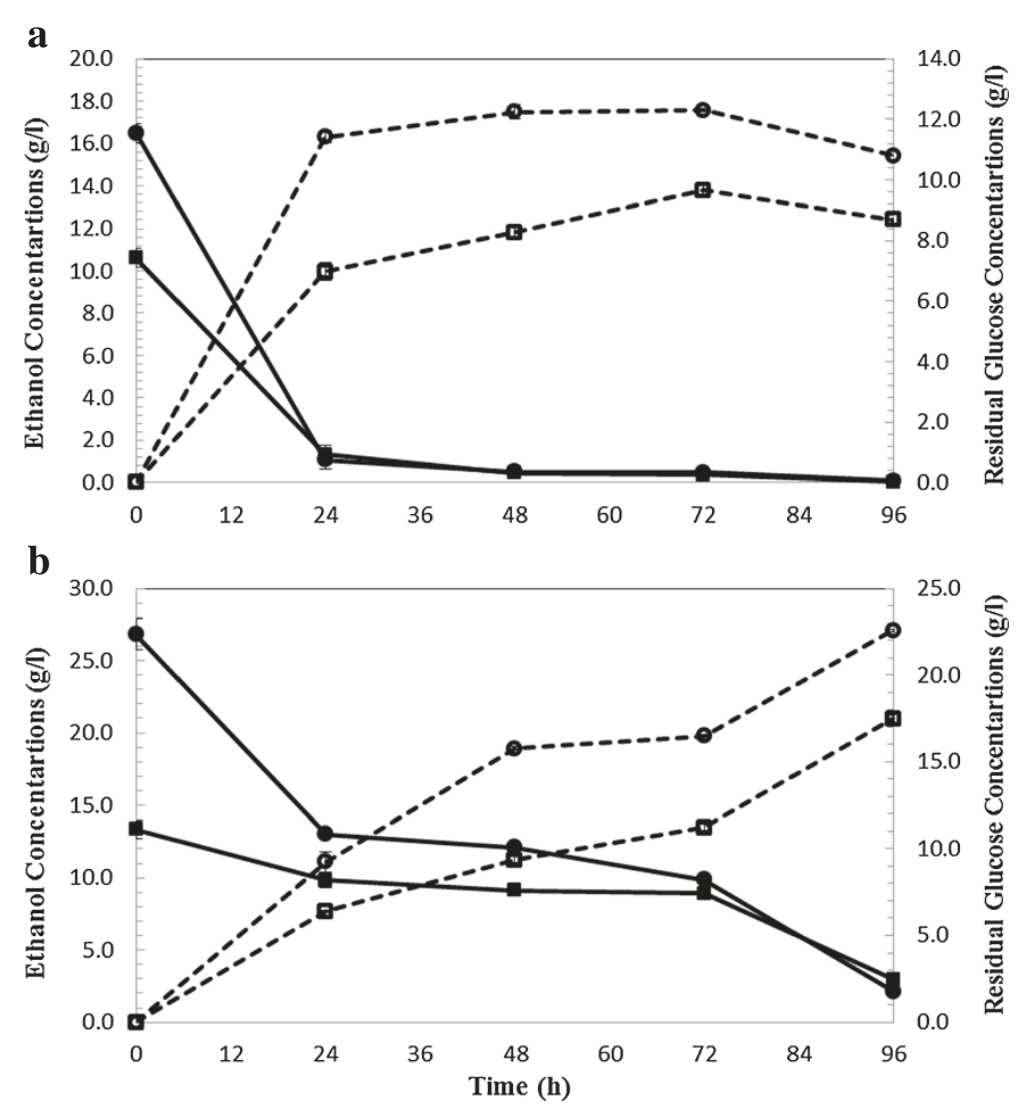

Figure 7 SSF ethanol production (dashed lines) and residual glucose (bold lines) from wet exploded Loblolly pine using commercial enzymes. (a) At 5\% solid loading and enzyme loading 5 FPU (squared label) and 15 FPU/g glucan (circled label). (b) At 10\% solid loading and enzyme loading $5 \mathrm{FPU}$ (squared label) and $15 \mathrm{FPU} / \mathrm{g}$ glucan (circled label).

the resulting ethanol concentration was higher than $5 \%$ SL but the yield was low considering the concentration of sugar. A high increase in glucose concentration can be observed at the beginning of SSF (until $48 \mathrm{hrs).} \mathrm{Glu-}$ cose concentration increased during the first 24 hours indicating that the hydrolysis rate superseded the fermentation rate. Stenberg et al. also observed the lag phase during SSF of softwood (Stenberg et al. 2000) at high solids loading with WIS concentrations of $10 \%$. They found that $10 \%$ WIS fermentation did not start within 96 hrs. Yields at higher solids loading (10\%) was slightly lower compared to $5 \%$ solid loading; however, the higher the solid loading during SSF, the lower the energy demand will be for the downstream processes such as distillation and concentration (Nguyen and Saddler 1991; Sun and Cheng 2002; Wingren et al. 2003). In other words, both high yield and higher ethanol concentration could be achieved by using higher solids loadings during SSF which will decrease the cost of production (von Sivers and Zacchi 1996; Wingren et al. 2003).

Generally our results are in the agreement with previous studies. Varga et al. (Varga et al. 2004) performed SSF with $12 \%$ solids loading and 22 FPU/g glucan resulting in an ethanol yield of $75 \%$. Öhgren et al. (Öhgren et al. 2006) reported $73 \%$ ethanol yield from SSF of corn stover at 10\% WIS and $25 \mathrm{FPU} / \mathrm{g}$ glucan using baker's yeast. In contrary, using nearly similar WIS loading (9\%), Sassner et al. (Sassner et al. 2006) found $20 \%$ ethanol yield from SSF acid impregnated and steam pretreated salix using $20 \mathrm{FPU} / \mathrm{g}$ glucan using baker's yeast. One of the advantages of wet explosion pretreatment is formation of less inhibitors which makes it favorable for yeast fermentation with lower enzyme addition.

Compared to SHF, ethanol production in SSF was substantially faster demonstrating lower enzyme inhibition by glucose. Wet explosion pretreatment and in-house produced enzymes (from $T$. reesei and A. saccharolyticus) were the catalyst responsible for achieving the higher ethanol concentration. Moreover, the most efficient configuration will be realized when both hydrolysis and fermentation share common optimal conditions. So far, there is no reported study on comparison of SHF and SSF of wet exploded corn stover and loblolly pine. However, in one study on alkaline-wet oxidized corn stover by Varga et al. (Varga et al. 2004) an overall ethanol yield of $84 \%$ 
was achieved at $12 \%$ solids loading and $43.5 \mathrm{FPU} / \mathrm{g}$ glucan enzyme loading. In other study on $\mathrm{SSF}$ of $\mathrm{SO}_{2}$-impregnated and steam pretreated spruce by Sternberg et al. (Stenberg et al. 2000), highest ethanol yield, $82 \%$ (from glucose and mannose combined) was achieved at 5\% solids loading and $32 \mathrm{FPU} / \mathrm{g}$ glucan. High enzyme loading is self-explanatory for higher yields of ethanol. Considering the cost of bioethanol production, cellulase cost is a critical parameter for process and cost improvement (Mielenz 2001). In this study we have minimized the addition of cellulases to demonstrate the possibilities of lowering the use of cellulase enzymes when using the wet explosion pretreatment for both corn stover and loblolly pine as feedstock.

Comparison between separate hydrolysis and fermentation (SHF) and simultaneous saccharification and fermentation (SSF) has resulted in the finding that SSF was more efficient compared to SHF, despite using a lower reaction temperature which is suboptimal for the enzyme hydrolysis reaction. The highest ethanol yields (75.98\% (WECS) and 67.07\% (WELP)) were achieved when WECS and WELP were hydrolyzed with $15 \mathrm{FPU} / \mathrm{g}$ glucan at $5 \%$ solids loading through a SSF process. Ethanol yield from loblolly pine was lower compared to corn stover in all fermentation experiments probably due to the presence of high concentrations of lignin in loblolly pine (the amount of lignin is nearly double compared to corn stover (Rana et al. 2012; Rana et al. 2013)). Lignin has been found to deactivate the action of enzymes by several researchers. Comparison of SSF with in-house enzymes and commercial enzymes showed slightly higher ethanol concentrations using commercial enzymes because of a faster cellulose conversion to glucose. This was probably due to additional accessory enzymes in the commercial product and also removal of undesired substances by purification in the commercial enzymes. Interestingly, we found no significant difference in the overall ethanol yields for samples hydrolyzed with commercial or on-site enzymes. These results indicate that there is a great potential for using in-house enzymes produced from for instance T. reesei and $A$. saccharolyticus as a substitute to using expensive commercial enzymes. Further work is needed to make this process more commercially attractive including purification and further concentration of in-house produced enzyme and using higher concentrations of pretreated solids and higher overall ethanol yields as well as optimization of some operational conditions.

\section{Competing interests}

The authors declare that they have no competing interests.

\section{Authors' contributions}

VR involved in the study concept, experiment design and execution, data interpretation, writing of manuscript and approving the final version to be published. ADE participated in designing of experiment and approved the final manuscript version. BKA supervised the design and progress of the experiments, edited and approved the final manuscript version. All authors contributed via discussion and have read and approved the final manuscript.

\section{Acknowledgement}

This work was financially supported by National Advanced Biofuel Consortium (NABC) and Department of Energy, Grant ZFT04064401.

Received: 6 June 2014 Accepted: 27 August 2014

Published: 11 September 2014

\section{References}

Ballesteros M, Oliva JM, Negro MJ, Manzanares P, Ballesteros I (2004) Ethanol from lignocellulosic materials by a simultaneous saccharification and fermentation process (SFS) with Kluyveromyces marxianus CECT 10875. Process Biochem 39(12):1843-1848, http://dx.doi.org/10.1016/j.procbio.2003.09.011

Bouws H, Wattenberg A, Zorn H (2008) Fungal secretomes-nature's toolbox for white biotechnology. Appl Microbiol Biotechnol 80(3):381-388, doi:10.1007/ s00253-008-1572-5

Dutta A, Dowe N, Ibsen KN, Schell DJ, Aden A (2010) An economic comparison of different fermentation configurations to convert corn stover to ethanol using Z. mobilis and Saccharomyces. Biotechnol Prog 26(1):64-72, doi:10.1002/btpr.311

Galbe M, Zacchi G (2002) A review of the production of ethanol from softwood. Appl Microbiol Biotechnol 59(6):618-628, doi:10.1007/s00253-002-1058-9

García-Aparicio M, Ballesteros I, González A, Oliva J, Ballesteros M, Negro M (2006) Effect of inhibitors released during steam-explosion pretreatment of barley straw on enzymatic hydrolysis. In: McMillan J, Adney W, Mielenz J, Klasson KT (eds) Twenty-seventh symposium on biotechnology for fuels and chemicals. ABAB symposium. Humana press., pp 278-288. doi:10.1007/978-1-59745-268-7_22

Himmel ME, Ruth MF, Wyman CE (1999) Cellulase for commodity products from cellulosic biomass. Curr Opin Biotechnol 10(4):358-364, http://dx.doi.org/ 10.1016/S0958-1669(99)80065-2

Ingesson H, Zacchi G, Yang B, Esteghlalian AR, Saddler JN (2001) The effect of shaking regime on the rate and extent of enzymatic hydrolysis of cellulose. J Biotechnol 88(2):177-182

Juhász T, Szengyel Z, Réczey K, Siika-Aho M, Viikari L (2005) Characterization of cellulases and hemicellulases produced by Trichoderma reesei on various carbon sources. Process Biochem 40(11):3519-3525, http://dx.doi.org/ 10.1016/j.procbio.2005.03.057

Kazi FK, Fortman JA, Anex RP, Hsu DD, Aden A, Dutta A, Kothandaraman G (2010) Techno-economic comparison of process technologies for biochemical ethanol production from corn stover. Fuel 89(Supplement 1):S20-S28, http://dx.doi.org/10.1016/j.fuel.2010.01.001

Klinke HB, Thomsen AB, Ahring BK (2004) Inhibition of ethanol-producing yeast and bacteria by degradation products produced during pre-treatment of biomass. Appl Microbiol Biotechnol 66(1):10-26, doi:10.1007/s00253-004-1642-2

Kovács K, Szakács G, Zacchi G (2009) Enzymatic hydrolysis and simultaneous saccharification and fermentation of steam-pretreated spruce using crude Trichoderma reesei and Trichoderma atroviride enzymes. Process Biochem 44(12):1323-1329, http://dx.doi.org/10.1016/j.procbio.2009.07.006

Kumar R, Singh S, Singh O (2008) Bioconversion of lignocellulosic biomass: biochemical and molecular perspectives. J Ind Microbiol Biotechnol 35 (5):377-391, doi:10.1007/s10295-008-0327-8

Linde M, Galb M, Zacchi G (2006) Steam pretreatment of acid-sprayed and acid-soaked barley straw for production of ethanol. Appl Biochem Biotechnol 130(1-3):546-562, doi:10.1385/abab:130:1:546

Linde M, Galbe M, Zacchi G (2007) Simultaneous saccharification and fermentation of steam-pretreated barley straw at low enzyme loadings and low yeast concentration. Enzyme Microb Technol 40(5):1100-1107, http://dx.doi.org/10.1016/j.enzmictec.2006.08.014

Liu ZL, Slininger PJ, Dien BS, Berhow MA, Kurtzman CP, Gorsich SW (2004) Adaptive response of yeasts to furfural and 5-hydroxymethylfurfural and new chemical evidence for HMF conversion to 2,5-bis-hydroxymethylfuran. J Ind Microbiol Biotechnol 31(8):345-352, doi:10.1007/s10295-004-0148-3

Lynd LR, Zyl WH, McBride JE, Laser M (2005) Consolidated bioprocessing of cellulosic biomass: an update. Curr Opin Biotechnol 16(5):577-583, http://dx.doi.org/10.1016/j.copbio.2005.08.009

McMillan JD (1997) Bioethanol production: Status and prospects. Renew Energy 10(2-3):295-302, http://dx.doi.org/10.1016/0960-1481(96)00081-X 
Mielenz JR (2001) Ethanol production from biomass: technology and commercialization status. Curr Opin Microbiol 4(3):324-329, http://dx.doi.org/ 10.1016/S1369-5274(00)00211-3

Nguyen QA, Saddler JN (1991) An integrated model for the technical and economic evaluation of an enzymatic biomass conversion process. Bioresour Technol 35(3):275-282, http://dx.doi.org/10.1016/0960-8524(91)90125-4

Öhgren K, Galbe M, Zacchi G (2005) Optimization of steam pretreatment of SO2impregnated corn stover for fuel ethanol production. In: Davison B, Evans B, Finkelstein M, McMillan J (eds) Twenty-sixth symposium on biotechnology for fuels and chemicals. ABAB symposium. Humana press., pp 1055-1067. doi:10.1007/978-1-59259-991-2_89

Öhgren K, Rudolf A, Galbe M, Zacchi G (2006) Fuel ethanol production from steam-pretreated corn stover using SSF at higher dry matter content. Biomass Bioenergy 30(10):863-869, http://dx.doi.org/10.1016/j.biombioe.2006.02.002

Oliva J, Sáez F, Ballesteros I, González A, Negro M, Manzanares P, Ballesteros M (2003) Effect of lignocellulosic degradation compounds from steam explosion pretreatment on ethanol fermentation by thermotolerant yeast Kluyveromyces marxianus. Appl Biochem Biotechnol 105(1-3):141-153, doi:10.1385/abab:105:1-3:141

Olsson L, Hahn-Hägerdal B (1993) Fermentative performance of bacteria and yeasts in lignocellulose hydrolysates. Process Biochem 28(4):249-257, http://dx.doi.org/10.1016/0032-9592(93)80041-E

Olsson L, Soerensen HR, Dam BP, Christensen H, Krogh KM, Meyer AS (2006) Separate and simultaneous enzymatic hydrolysis and fermentation of wheat hemicellulose with recombinant xylose utilizing saccharomyces cerevisiae. In: McMillan J, Adney W, Mielenz J, Klasson KT (eds) Twenty-seventh symposium on biotechnology for fuels and chemicals. ABAB symposium. Humana press., pp 117-129. doi:10.1007/978-1-59745-268-7_9

Rana D, Rana V, Ahring BK (2012) Producing high sugar concentrations from loblolly pine using wet explosion pretreatment. Bioresour Technol 121:61-67, http://dx.doi.org/10.1016/j.biortech.2012.06.062

Rana V, Rana D, Ahring B (2013) Process modeling of enzymatic hydrolysis of wetexploded corn stover. Bioenergy Res:1-10, doi:10.1007/s12155-013-9384-6

Rana V, Eckard AD, Teller P, Ahring BK (2014) On-site enzymes produced from Trichoderma reesei RUT-C30 and Aspergillus saccharolyticus for hydrolysis of wet exploded corn stover and loblolly pine. Bioresour Technol 154:282-289, http://dx.doi.org/10.1016/j.biortech.2013.12.059

Sassner P, Galbe M, Zacchi G (2006) Bioethanol production based on simultaneous saccharification and fermentation of steam-pretreated Salix at high dry-matter content. Enzyme Microb Technol 39(4):756-762, http://dx.doi.org/10.1016/j.enzmictec.2005.12.010

Schell D, Hinman N, Wyman C, Werdene P (1990) Whole broth cellulase production for use in simultaneous saccharification and fermentation. Appl Biochem Biotechnol 24-25(1):287-297, doi:10.1007/bf02920253

Stenberg K, Bollók M, Réczey K, Galbe M, Zacchi G (2000) Effect of substrate and cellulase concentration on simultaneous saccharification and fermentation of steam-pretreated softwood for ethanol production. Biotechnol Bioeng 68(2):204-210, doi:10.1002/(sici) 1097-0290(20000420)68:2<204:.aid-bit9>3.0.c0;2-4

Sun Y, Cheng J (2002) Hydrolysis of lignocellulosic materials for ethanol production: a review. Bioresour Technol 83(1):1-11, http://dx.doi.org/10.1016/ S0960-8524(01)00212-7

Taherzadeh MJ, Niklasson C, Lidén G (1999) Conversion of dilute-acid hydrolyzates of spruce and birch to ethanol by fed-batch fermentation. Bioresour Technol 69(1):59-66, http://dx.doi.org/10.1016/S0960-8524(98)00169-2

Taherzadeh MJ, Gustafsson L, Niklasson C, Lidén G (2000) Physiological effects of 5-hydroxymethylfurfural on Saccharomyces cerevisiae. Appl Microbiol Biotechnol 53(6):701-708, doi:10.1007/s002530000328

Tomás-Pejó E, Oliva JM, Ballesteros M, Olsson L (2008) Comparison of SHF and SSF processes from steam-exploded wheat straw for ethanol production by xylose-fermenting and robust glucose-fermenting Saccharomyces cerevisiae strains. Biotechnol Bioeng 100(6):1122-1131, doi:10.1002/bit.21849

Varga E, Klinke HB, Réczey K, Thomsen AB (2004) High solid simultaneous saccharification and fermentation of wet oxidized corn stover to ethanol. Biotechnol Bioeng 88(5):567-574, doi:10.1002/bit.20222

von Sivers M, Zacchi G (1996) Ethanol from lignocellulosics: a review of the economy. Bioresour Technol 56(2-3):131-140, http://dx.doi.org/10.1016/09608524(96)00018-1

Wen ZY, Liao W, Chen SL (2004) Hydrolysis of animal manure lignocellulosics for reducing sugar production. Bioresour Technol 91(1):31-39, doi:10.1016/ S0960-8524(03)00166-4
Wingren A, Galbe M, Zacchi G (2003) Techno-economic evaluation of producing ethanol from softwood: comparison of SSF and SHF and identification of bottlenecks. Biotechnol Prog 19(4):1109-1117, doi:10.1021/bp0340180

Xiao Z, Zhang X, Gregg D, Saddler J (2004) Effects of sugar inhibition on cellulases and $\beta$-glucosidase during enzymatic hydrolysis of softwood substrates. Appl Biochem Biotechnol 115(1-3):1115-1126, doi:10.1385/ abab:115:1-3:1115

Zaldivar J, Roca C, Le Foll C, Hahn-Hägerdal B, Olsson L (2005) Ethanolic fermentation of acid pre-treated starch industry effluents by recombinant Saccharomyces cerevisiae strains. Bioresour Technol 96(15):1670-1676, http://dx.doi.org/10.1016/j.biortech.2004.12.034

doi:10.1186/2193-1801-3-516

Cite this article as: Rana et al: Comparison of SHF and SSF of wet exploded corn stover and loblolly pine using in-house enzymes produced from $T$. reesei RUT C30 and A. saccharolyticus. SpringerPlus 2014 3:516.

\section{Submit your manuscript to a SpringerOpen ${ }^{\odot}$ journal and benefit from:}

- Convenient online submission

- Rigorous peer review

- Immediate publication on acceptance

- Open access: articles freely available online

- High visibility within the field

- Retaining the copyright to your article

Submit your next manuscript at $>$ springeropen.com 